\title{
Governing Decentral Energy Systems
}

\section{Triangulating Between Uniform European and National Standards and Locally Optimized Energy Regimes}

\author{
Peter Hettich
}

\begin{abstract}
Contents

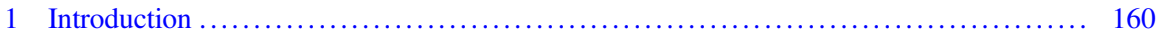

2 Decentralization of the Swiss Energy System ................................ 160

2.1 Vertically Integrated State-Owned Monopolies ........................... 160

2.2 Gradual Strengthening of Decentral Producers .......................... 162

3 Centralization of Swiss Energy Governance .................................. 163

3.1 Energy Governance on the Federal Level .............................. 163

3.2 Energy Governance on the European Level ............................ 164

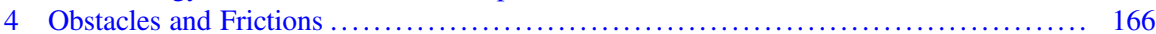

$4.1 \quad$ Field Test "aliunid" .................................................. 166

4.2 Possible (Legal) Obstacles to Implement the Business Model .................... 167

4.3 Workarounds and Legal Recommendations ............................. 170

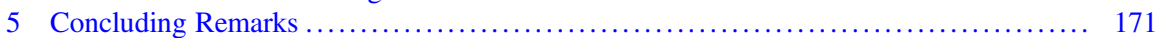

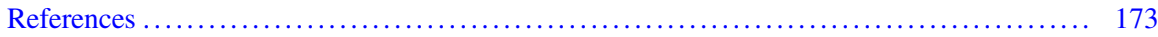

\begin{abstract}
Against the backdrop of an energy system moving from vertically integrated monopolies towards a decentral system with a multitude of actors in everchanging roles, we observe a gradual strengthening of central governance mechanisms on the nation-state and on the European level. Such a top-down approach to the governance of the energy system might have been necessary to open up energy markets to competitive processes and innovation. With social goals shifting and security of supply and environmental concerns gaining importance, the governance of the energy system has to be reshaped anew, enabling, e.g., the optimization of regional energy systems by local actors. In particular, strict unbundling rules may hinder or preclude system-serving behavior, to the detriment of all market participants and consumers. Lawmakers and regulators should provide some leeway to cooperative approaches, such as the empowerment of local actors to devise their own energy regimes.
\end{abstract}

\section{P. Hettich $(\triangle)$}

Institute of Public Finance, Fiscal Law and Law and Economics, University of St. Gallen,

St. Gallen, Switzerland

e-mail: peter.hettich@unisg.ch

(C) The Author(s) 2022 


\section{Introduction}

The design of a country's electricity supply system can be centralized or decentralized. In Switzerland, discussions on this subject began at the turn of the nineteenth century, with the advent of electrification. ${ }^{1}$ For the understanding of the present paper, it is important that the different designs of the supply systems in individual countries are not the result of a search and discovery process initiated by market competition, but the result of a deliberative political decision of intervention or non-intervention. In Switzerland, a decision of non-intervention by the federal authorities gave rise to a mostly centralized electricity supply system governed by the cantons; this system is slowly becoming more decentralized, mostly driven by federal and European regulation. Thus, the central governance mechanisms inherent in federal and European regulations have provided important boosters to transform the energy system. However, central governance may also frustrate local initiatives and take away opportunities to modify and optimize the performance of local energy systems. Thus, decision-making at a higher level may help to steer communities towards a common goal, but it might come with losses of efficacy and efficiency.

Consequently, this chapter explores frictions, sometimes quite hidden, at the interfaces of the European, federal, cantonal, and communal level, which affect the behavior of participants in the energy market. While the current shift towards a decentralized and more renewable electricity supply would not have been possible without a kickstart on the European and federal level, this author argues that rigid legislation on the central level hinders-somewhat counterintuitively-further progress towards an environmentally sustainable electricity supply.

At first, we will look at the development of a more interventionist approach at the central levels of government before we discuss the obstacles which the current set of rules and regulations pose for a more sustainable electricity system. We conclude with proposals that could lift these obstacles, providing more leeway for local actors while safeguarding the public interests that might be seen threatened by a less interventionist approach.

\section{Decentralization of the Swiss Energy System}

\subsection{Vertically Integrated State-Owned Monopolies}

Theoretically, competitive markets realize the economic welfare optimum. In reality, however, particularly looking at grid-bound energy supply, various plausible reasons for market failure and other "market imperfections" exist. These market imperfections may justify economic policy interventions.

\footnotetext{
${ }^{1}$ Walther (2014), p. 31.
} 
Network effects in energy markets give rise to natural monopolies, which tend to form vertically integrated energy suppliers. These suppliers extend the reach of their grid monopolies into upstream and downstream markets (i.e., into the markets for energy production and energy distribution).

Further, the long-term nature of investment decisions gives rise to concerns as to whether the private markets create sufficient incentives for investments. In particular, prices in electricity markets are linked to short-term marginal costs of production due to the lack of storage. Consequently, the fixed costs of production are considered as "sunk" and as not relevant to the decision on the use of a power plant. The recovery of the full costs of a power plant in the electricity market is only achieved by temporary price peaks; these peak prices are the most important refinancing source for power plant investments. If such phases with higher prices do not occur or if such phases are counteracted by regulation, incentives for new investments are strongly reduced. This so-called "missing money problem" may trigger interventions by the state to encourage new investments. Indeed, the public sector (in Switzerland the cantons and municipalities) provides for a large share of the capital of the electricity and the gas industry. Even compared with institutional investors, the public sector has a high capacity to bear the long-term risks associated with investments in the energy sector. ${ }^{2}$ Still, there are concerns regarding the survival of the Swiss hydropower plants: Because of its historically large profits, this backbone of the Swiss electricity supply does not profit so much from subsidies but is rather subject to taxation (fees for water rights, "Wasserzins"); efforts to change this or to adapt the current system of taxation have not made much progress, so far.

The Swiss Confederation enacted legislation on the electricity sector already in 1902 (Electricity Act, Elektrizitätsgesetz); legislation on the oil and gas sector was enacted in 1963 (Pipelines Act, Rohrleitungsgesetz). However, these legislative acts are mainly concerned with the planning and safety of electricity lines and pipelines. Consequently, most issues that are relevant to the organization of the energy markets have been left to cantonal legislation. For the reasons stated above, the cantons and municipalities were invested heavily in the energy markets; they had little interest in regulating the energy sector, since this would only serve to limit the entrepreneurial leeway that their state-owned monopoly enterprises had so far enjoyed. The market structure resulting from this non-intervention policy was shaped by nearly 800 municipal and cantonal energy suppliers, which enjoyed local and regional monopoly powers. These state-owned enterprises were deeply enmeshed in politics, which resulted in moderated pricing. Since there was no competition for consumers, horizontal cooperation was abundant, resulting, for example, in many joint electricity power plants in the Swiss alps (mostly pump storage power plants).

\footnotetext{
${ }^{2}$ Hettich et al. (2017), p. 26 et seq.
} 


\subsection{Gradual Strengthening of Decentral Producers}

The Resolution on Energy Use of 1990 (Energienutzungsbeschluss) forced grid operators to purchase the electricity offered by small producers. The provision significantly strengthened the position of renewable electricity producers, since suppliers had to purchase "energy not produced on a regular basis" as well. Small hydroelectric power plants as well as producers using new renewable energies (solar energy, biomass including biogas, geothermal energy, wind, etc.), waste energy, and combined heat and power generation were able to benefit from the provision. The Federal Council held that these producers would help to secure and to diversify energy supply, in particular in times of crisis. The remuneration that had to be paid was not intended to subsidize renewable energy producers; nevertheless, these producers were compensated (initially) with $0.16 \mathrm{CHF} / \mathrm{kWh}{ }^{3}$ This first timid step towards decentralization was enshrined in permanent law with the Energy Act of 1998 (Energiegesetz); since then, independent producers have a legal right to feed their electricity into the grids. Starting 2005, grid operators were allowed to ask for a surcharge on the transmission costs of their grids in order to finance the remuneration of the independent producers (Additional Cost Financing, Mehrkostenfinanzierung). By implementing this change, a proto-system to decentralize electricity supply was put in place.

While the European Union enabled electricity consumers to freely choose their electricity supplier, the first attempt of the Swiss Confederation to liberalize its markets failed. In order to overcome the resistance of the socialist party and the trade unions, the Swiss legislator significantly enhanced the feed-in rights of independent suppliers. In contrast to the situation in 1990, the enhanced feed-in rights were meant to increase the share of renewable energy in the electricity system; the reliability of the energy infrastructure and the ability of energy providers to meet current and future demand were less a concern. The improved prospect for renewable energy providers was enough to secure the political acceptance necessary to liberalize the electricity markets for large consumers. Since then, a plethora of subsidies have been paid out not only to small but also to large renewable energy producers. Nevertheless, in 2020, the share of decentral producers in electricity generation was still timid: $3.97 \%$ photovoltaics, $0.22 \%$ wind, and $0.87 \%$ biomass. ${ }^{4}$ The share of new renewables in primary energy consumption is negligible. ${ }^{5}$ In fact, the decarbonisation of the energy supply has not even really started yet. Despite the energy system mostly producing in central power plants at this point in time, we acknowledge that the buildup of photovoltaic capacity has been impressive during the last years; electricity generation by photovoltaics constitutes the main driver for the decentralization of the energy system.

\footnotetext{
${ }^{3}$ Federal Council (1988), p. 515 et seq.

${ }^{4}$ Swiss Federal Office of Energy (2021), p. 6.

${ }^{5}$ Swiss Federal Office of Energy (2021), p. 5.
} 
This being said, decentralization is not a goal per se, but rather seen as an instrument to maintain a carbon-free (mostly renewable) electricity supply in Switzerland, even after the phaseout of the nuclear energy plants. A mix of mostly legal factors, which are explained below in more detail, contributes to the rapid expansion of photovoltaics: a provision of direct subsidies, even for large electricity suppliers; a secure legal status for independent prosumers (feed-in rights); as well as consumption-based grid charges that benefit prosumers (consumption-based grid charges generate a cross-subsidy that is paid by normal households; the depressing effects on profits of the utilities are also known as the "utility death spiral"). ${ }^{6}$ Of course, other factors-declining costs of generation, increasing social acceptance, utilities located in progressive cities investing in new renewables, etc.- - have contributed to this development as well.

\section{Centralization of Swiss Energy Governance}

The shift towards decentralization, although still timid, is enabled by regulation, mostly enacted on the federal level. In addition, European regulation is strongly influencing the shape of federal regulation, despite the fact that Switzerland is not a member of the European Union.

\subsection{Energy Governance on the Federal Level}

Federal regulation sets the most important parameters for decentralization: The law defines decentral producers by setting a cap on capacity and power generation. Decentral producers below this cap have an unrestricted right to feed their energy into the grid for free, regardless of actual electricity demand and regardless of production by other producers (priority of dispatch). ${ }^{7}$ The basic compensation that the grid operator is required to pay to decentral producers is fixed by law as well ${ }^{8}$ although the basic compensation is not intended to subsidize decentral producers, some "progressive" utilities set a higher basic rate in order to incentivize decentral production. For decentral producers participating in the Swiss support scheme, a subsidy is paid out to cover the actual costs of production and to alleviate market risks; today, the subsidy takes the form of a one-off contribution or of a sliding market premium (replacing the earlier fixed feed-in premium model). ${ }^{9}$

\footnotetext{
${ }^{6}$ Hettich and Walther (2015), p. 24 et seq.

${ }^{7}$ Art. 15 para. 1 and 2 Energy Act (Energiegesetz).

${ }^{8}$ Art. 15 para. 3 Energy Act (Energiegesetz).

${ }^{9}$ Art. 19 and 25 Energy Act (Energiegesetz).
} 
Since the subsidies are declining and, if the government keeps its promise, due to be phased out, other factors have become important for decentral producers. In particular, the number of prosumers (mostly decentral solar electricity generators making use of their right for self-consumption) has risen due to the structure of grid tariffs for low-voltage households. Federal law holds that grid charges for households shall predominantly be consumption-based. ${ }^{10}$ Consequently, prosumers participate only to a partial extent in the effective costs they cause to the distribution network, since these effective costs are mainly caused by installed capacity. Hence, prosumers benefit from an (indirect) subsidy that can be regarded as a crosssubsidization by other users of the distribution network (i.e., people who do not own real estate). ${ }^{11}$

Last but not least, many decentral producers are households that profit from legal provisions protecting "vulnerable consumers". The tariff for electricity supply as well as the grid charges are cost-based and, in principle, fixed for the duration of a whole year. ${ }^{12}$ The law basically bans discriminating tariffs between normal households and prosumers. Households and small businesses have a legal right to purchase all the electricity they need, thereby rendering demand-side management of households virtually impossible. ${ }^{13}$

\subsection{Energy Governance on the European Level}

At the time of writing, Switzerland is neither a member of the European Union (EU) nor is it bound to adhere to EU law due to bilateral cooperation agreements. Nevertheless, EU law deeply affects the shape of Swiss energy regulation due to effects of indirect "Europeanization". ${ }^{14}$ Since 2007, Switzerland and the EU have been negotiating an electricity agreement that would allow Switzerland to participate in the mechanisms of European energy governance and to trade electricity on an equal footing with its European competitors. With only a few points of the electricity agreement remaining controversial, the main obstacle to conclude the agreement are open institutional questions. Negotiations on an institutional agreement have been ongoing since 2012; their successful conclusion, farther away than ever, is a precondition for any new agreement on market access. ${ }^{15}$

During the negotiations, the EU's internal energy market has evolved considerably, having reached a high degree of formalization of its institutions and

\footnotetext{
${ }^{10}$ Art. 14 para. 3 Electricity Supply Act (Stromversorgungsgesetz) and Art. 18 para. 3 Electricity Supply Ordinance (Stromversorgungsverordnung).

${ }^{11}$ Hettich and Walther (2015), p. 24 et seq.

${ }^{12}$ Art. 6 para. 3 and 4 Electricity Supply Act (Stromversorgungsgesetz).

${ }^{13}$ Art. 6 para. 1 Electricity Supply Act (Stromversorgungsgesetz).

${ }^{14}$ See for mechanisms of "Europeanization" Knill and Lehmkuhl (2002), p. 255 et seq.

${ }^{15}$ Hettich et al. (2020), p. 92.
} 
regulations. In November 2016, the European Commission brought forward a package of legislative proposals ("Clean Energy for all Europeans"), which was adopted by the European Parliament and Council and entered into force in 2018 and 2019. In contrast, Switzerland has not yet fully implemented the 3rd package on the internal energy market, which was adopted by the EU already in 2009. Although the draft electricity agreement has never been published, it may reasonably be expected that Switzerland would have to adapt its energy governance to the one of the EU.

An electricity agreement would contain rules on state aid, as required by the draft institutional agreement. ${ }^{16}$ However, the recast renewable energy directive still allows for subsidy schemes for electricity generation from renewable sources, as long as these subsidy schemes are as non-distortive as possible for the functioning of the electricity markets. In particular, the directive exempts small (decentral) installations from market-based allocations of subsidies in order to support their rollout. ${ }^{17}$ Despite the fact that most support schemes fall within the scope of the European state aid rules, ${ }^{18}$ the Guidelines of the European Commission on State aid for environmental protection and energy for the years $2014-2020^{19}$ provide for ample scope when designing subsidy schemes (the adoption of new Guidelines is foreseen for the end of 2021). Further and somewhat unexpected, the European Court of Justice, in a landmark decision issued on 28 March 2019, has ruled that the German promotion scheme does not constitute "state aid" according to European law. ${ }^{20}$ Since Switzerland has modeled its own subsidy scheme on Germany's promotion scheme, it might retain considerable autonomy when supporting renewable energy generators. ${ }^{21}$

With regard to the indirect support of decentral producers through the exemption from grid charges, the Commission recognizes the wide variety of tariff structures across the EU; so far, the EU has refrained from harmonizing distribution tariff structures and methodologies. ${ }^{22}$ A proposal to empower the European Commission to adopt delegated acts concerning the establishment of network codes in the area of harmonized transmission and distribution tariff structures and connection charges has been dropped in the course of the negotiations on the Electricity Regulation. However, after trilogue negotiations, the Commission and the Council agreed that the Agency for the Cooperation of Energy Regulators (ACER) "shall provide a best practice report on transmission and distribution tariff methodologies while taking account of national specificities"; the Agency's recommendation shall be taken duly into consideration by regulatory authorities when approving or fixing transmission

\footnotetext{
${ }^{16}$ Art. 8A-8C Draft Institutional Agreement between Switzerland and the EU.

${ }^{17}$ Recital 17 et seq. Directive 2018/2001 of the European Parliament and of the Council of 11 December 2018 on the promotion of the use of energy from renewable sources, OJ L 328, 21 December 2018, 82-209.

${ }^{18}$ Art. 107 of the Treaty on the Functioning of the European Union.

${ }^{19}$ OJ C 200, 28.6.2014, 1-55.

${ }^{20}$ Bundesrepublik Deutschland v Europäische Kommission, ECJ C-405/16 of 28 March 2019.

${ }^{21}$ Hettich et al. (2020), p. 8.

${ }^{22}$ European Commission (2016), p. 164 and 171.
} 
or distribution tariffs. ${ }^{23}$ Although this indicates some move towards more central governance, the impact of the new electricity regulation on grid charges in the EU member states as well as in Switzerland seems rather small. ${ }^{24}$

\section{Obstacles and Frictions}

The specific regulations mentioned above do not touch on cross-border trade with electricity. Looking at small electricity generators, the new European regulations in this area are hardly required to guarantee the functioning of the EU's internal electricity market. Thus, while indeed providing a strong boost to the rollout and deployment of decentral renewable energy infrastructures, we also need to analyze the drawbacks that come with increased central-i.e., European-governance of the electricity markets. In order to identify legal obstacles and frictions towards the transformation of a carbon-free energy system (the Swiss electricity system is mostly carbon-free already), our institute has participated in a field test of the Swiss Federal Office of Energy, the results of which will be discussed in detail in this chapter. ${ }^{25}$

\subsection{Field Test "aliunid"}

The enterprise "aliunid" is a joint venture of several energy providers, grid operators and energy producers; as a white-label-product, it provides smart home and smart business solutions to households and SMEs. For utilities, aliunid analyzes energy flows in households, boroughs, municipalities as well as larger regions. Based on real-time data, aliunid helps to optimize local and regional energy supply and consumption, thereby saving grid costs and electricity for balancing.

Aliunid tries to exploit a weakness of a predominantly renewable energy system. Looking at electricity supply, renewable energy systems rely on many small, decentral electricity producers, which mainly make use of solar and wind energy. This renders the energy system highly dependent on the weather. Since production can no longer easily be adjusted to demand, flexibilities on the demand side and storage options become more important.

Households, in particular prosumers with photovoltaic arrays and storage devices (at-home batteries, electric vehicles, heat pumps, electric water boilers), dispose of many small but-if aggregated—significant flexibilities. At best, these flexibilities

\footnotetext{
${ }^{23}$ Art. 18 para. 9 et seq. Regulation 2019/943 of the European Parliament and of the Council of 5 June 2019 on the internal market for electricity, OJ L 158, 14 June 2019, 54-124.

${ }^{24}$ Hettich et al. (2020), p. 27.

${ }^{25}$ See Moeller, press release of 7 May 2019, available at https://energeiaplus.com/2019/05/07/ aliunid-startet-feldtest-mit-iot-plattform.
} 
are used to optimize the household's electricity or overall energy consumption. By using its flexibility options, a household may save on electricity and grid costs. However, such an optimization does not necessarily reduce system costs. The electricity cost of the supplier depends on system-wide demand, with prices rising sharply during peak times; peak times on the system level do not necessarily correlate with peak demand on the household level. Furthermore, grid costs of households depend on the maximum capacity that is provided; an optimization of electricity demand on the household level focusing on saving individual grid costs does not necessarily reduce the peak capacity—maybe required just once a year—of a specific household. That households are left indifferent to situations of peak demand constitutes a negative externality. Thus, incentives for households to include system costs into their optimization efforts are needed.

One purpose of aliunid is to bundle a large number of flexibility options. This enables internal offsetting of flexibilities (e.g., by using the battery storage of a household to reduce peak demand in a certain region); bundling also reduces transaction costs, enabling aliunid to market its flexibilities on a wholesale basis and to generate revenues. Taking into account the needs of households, municipalities and regions at the same time, aliunid may indeed help to save on grid costs, at least in the long run. With many smart devices connected to the home's smart meter, aliunid generates an additional revenue flow by providing smart home solutions. Needless to say, this business model is heavily dependent on real time data; in an ideal world, this data would update every $1-5 \mathrm{~s}$.

\subsection{Possible (Legal) Obstacles to Implement the Business Model}

There are several obstacles to overcome in order to turn aliunid into a sweeping success; unfortunately, many of these obstacles are "self-inflicted", unnecessary regulatory burdens.

\subsubsection{Low Market Value of Flexibility}

First of all, the efficient marketing of flexibility options may help the transformation of the energy system, but the financial rewards are limited at this point in time, for several reasons. Flexibility options compete with the costs of generating additional electricity, which are, despite recent price hikes, still quite low throughout Europe; generation from wind and solar plants has risen sharply while fossil power plants, in particular coal power plants, are still operating. Consequently, looking at Switzerland, the purchase price for flexibility options is capped by the costs of importing additional electricity from neighboring countries. In a peculiar way, the abstention of Switzerland from the EU's common market in energy helps to make flexibility 
options more profitable, since transaction costs for cross-border trade of electricity remain high. ${ }^{26}$

\subsubsection{Postage Stamp Principle for Grid Charges}

Another reason for the low value of flexibility lies with the structure of the grid charges: The law requires grid operators to apply the "postage stamp principle" on their tariffs, meaning that network usage tariffs are to be calculated independently of the distance between entry and exit point of the electricity. ${ }^{27}$ The "postage stamp principle" is sensible for a centralized energy system because it protects captured consumers from monopolistic suppliers that purchase electricity from afar; against this backdrop, the "postage stamp principle" embodies considerations of equity and fairness. The cantons may even choose to establish a fund to compensate for unequal grid charges, though no canton has taken such measures so far. ${ }^{28}$ In a decentral energy system, however, uniform grid charges provide no incentives to optimize the energy system on a local or regional level. Given the fact that local electricity producers indeed may help to obviate expansions of the electricity grid, the "postage stamp principle" does not reward investments in local electricity generation, thereby rendering local consumers of electricity indifferent to the costs of "their" electricity network.

In 2019, the independent regulatory agency for the electricity markets (ElComElectricity Commission) issued a notice on "innovative and dynamic grid usage and energy supply tariffs". ${ }^{29}$ It held that consumers may be offered a choice of grid tariffs; however, these tariffs need to fulfill the legal requirements, somewhat limiting the range of possible choices. It also held that dynamic tariffs are "not per se illegal", but need to adhere to the (inherently static) principles set by the law. "Smart Grid Ready" tariffs need to observe a range of requirements, which gives rise to legal risks when they are used. There are no incentives to optimize the local energy system, since - according to ElCom - it is illegal to reward such optimization by reimbursing consumers with parts of the avoided grid costs. ${ }^{30}$ At least, networkserving and system-serving behavior of consumers using smart control systems may be rewarded by providing financial incentives. ${ }^{31}$ Finally, the Electricity Commission held that dynamic electricity pricing might be illegal in light of universal service

\footnotetext{
${ }^{26}$ For a detailed description of cross-border trade with the European Union and the mechanism of "market coupling", see Hettich et al. (2015), p. 21 et seq. See for cost estimates Van Baal et al. (2019), p. 38.

${ }^{27}$ Art. 14 para. 3 lit. b Electricity Supply Act (Stromversorgungsgesetz).

${ }^{28}$ See for the structure of grid charges Federal Council (2005), p. 1652 et seq.

${ }^{29}$ ElCom (2019), p. 3 et seq.

${ }^{30} \mathrm{ElCom}$ (2019), p. 5.

${ }^{31}$ Art. $8 \mathrm{c}$ para. 2 Electricity Supply Ordinance (Stromversorgungsverordnung).
} 
obligations. ${ }^{32}$ A flat rate for electricity supply, however, is in line with the legal requirements; of course, such a flat rate provides no incentives to adapt electricity consumption at all. ${ }^{33}$

\subsubsection{Restrictive Use of Smart Meter Data}

Smart energy and smart home services require data. Accumulating and processing the data enables the effective and efficient functioning of the smart grid. In order to provide its energy services, aliunid needs data about actual electricity consumption, actual electricity production, as well as a home's potential for additional electricity consumption and additional production; due to privacy concerns, this data only is available to aliunid in a condensed and aggregated form. In order to provide additional smart home and smart business services, aliunid further needs smart meter data from all smart devices and home appliances, as well as from additional sensors and security systems; for the same privacy concerns, most of this data will only be stored and analyzed locally.

Nevertheless, the gathering of data touches on sensitive issues: On the one hand, data is collected from end consumers, whose personal rights must be protected; on the other hand, information on the operation of the power supply system is exchanged, which can be critical for system stability. Data protection, in the sense of protecting personal data against misuse, and data security, in the sense of protecting data against loss, falsification, damage or deletion by organizational and technical measures and by software, must therefore be guaranteed. ${ }^{34}$ Furthermore, the law states that economically sensitive information obtained from the operation of the electricity grids shall be treated confidentially by the electricity supply companies, subject only to statutory disclosure obligations; hence, this data must not be used for other areas of economic activity (so-called "informational unbundling"). ${ }^{35}$

As a basic principle, the use of intelligent control systems requires the consent of the affected final consumers, producers and storage facilities. ${ }^{36}$ Network operators may process the data gathered from intelligent control systems without consent for the management of the grid: First, they may legally use personality profiles and personal data in pseudonymized form, including load profiles of fifteen minutes and more, for the measurement of electricity flows, for the control and regulation of the grid, for the use of tariff systems, and for the operation, balancing and planning of

\footnotetext{
${ }^{32}$ See for this interpretation of Art. 6 para. 3 Electricity Supply Act (Stromversorgungsgesetz); ElCom (2019), p. 8.

${ }^{33}$ ElCom (2019), p. 7 et seq.

${ }^{34}$ A consortium with participation of the University of St. Gallen has conducted two studies on data protection and data security of the smart grid, the results of which are summarized in Hettich and Rechsteiner (2014), n. 1.

${ }^{35}$ Art. 10 para. 2 Electricity Supply Act (Stromversorgungsgesetz); see also Hettich and Rechsteiner (2014), n. 5.

${ }^{36}$ Art. 17b para. 3 Electricity Supply Act (Stromversorgungsgesetz).
} 
the network. Second, they may also use personality profiles and personal data in non-pseudonymized form, including load profile values of fifteen minutes or more, for billing purposes (billing for energy supply, grid usage and remuneration for the use of the control systems). ${ }^{37}$ According to a recent draft amendment for the Electricity Supply Act, all processing of smart meter data, which is not necessary for fulfilling the task of electricity supply, may only be carried out with the express consent of the persons concerned. ${ }^{38}$

Against the backdrop of these restrictions, the express consent seems required for all personal data with a higher granularity than fifteen minutes (if available at all), as well as for all data that is not required for billing purposes or for grid management. ${ }^{39}$ Such a regime is even more rigid than the general data protection laws, which also allow for data processing if a legitimate interest of the concerned business is involved. ${ }^{40}$ Thus, it is reasonable to say that network operators and other players in the smart grid may not be able to easily tap the huge potential of data from intelligent systems, e.g., for smart home and security services or for personalized advertising. ${ }^{41}$ Such enhanced services, however, may be necessary to generate a reasonable return on the investments of the utilities in the smart grid. Looking generally at the current regime of data protection, a move towards a more riskbased approach and a holistic system of information governance might be required to enhance many of the information-based services provided today.

\subsection{Workarounds and Legal Recommendations}

Aliunid is one of many smart energy providers that have developed business models to support the transformation towards a carbon-free energy system. ${ }^{42}$ Because of current policies, this transformation is accompanied by a decentralization of the energy system. This move towards a decentral energy system is not reflected in the current regulatory framework. There is no specific incentive to optimize local grid usage: Because of the "postage stamp principle", transporting electricity over long distances costs the same as using local production. There is no specific incentive to adapt consumption to current demand because the reward for flexibility is so low.

\footnotetext{
${ }^{37}$ Art. 8d para. 1 Electricity Supply Ordinance (Stromversorgungsverordnung).

${ }^{38}$ Draft Amendment of 18 June 2021 for Art. $17 \mathrm{~b}^{\text {quater }}$ and $17 \mathrm{c}$ Electricity Supply Act; see also, more clearly, the earlier Draft Amendment of 17 October 2018 for Art. $17 b^{\text {ter }}$ Electricity Supply Act (Stromversorgungsgesetz).

${ }^{39}$ Federal Council (2018), p. 70; Federal Council (2021), p. 102.

${ }^{40}$ See Rechsteiner and Steiner (2018), n. 56 et seq., arguing for a more expansive application of the law.

${ }^{41}$ Rechsteiner and Steiner (2018), n. 42.

${ }^{42}$ Looking at Switzerland, the electricity system is mostly carbon-free at this point in time, thanks to large generation capacities that make use of nuclear and hydro energy. The challenge will be to maintain this environmentally friendly status despite the planned nuclear phaseout.
} 
There are rather weak incentives for small prosumers to adapt electricity generation to current demand because their subsidies are mostly fixed and their marginal costs of production are very low. There are no specific provisions on storage (e.g., batteries, Power2X), making it difficult to distinguish self-serving and systemserving storage devices; without such distinction, rewarding the flexibility provided by storage is hardly feasible. Last but not least, the commercial use of smart meter data is very much dependent on consent, which needs to be freely given on an informed basis.

On the upside, the current regulatory framework does not preclude innovative business models in the energy sector. Financial incentives to reward system-serving behavior via dynamic grid charges and electricity tariffs are possible, although quite limited because of the legal requirements that have to be adhered to. Available flexibilities of consumers and prosumers may be harnessed by using contractual arrangements.

The legal requirements for informational unbundling are more challenging to meet: Economically sensitive information obtained from the operation of the electricity grids may not be used for other areas of commercial activity. Aliunid, however, does not qualify as a grid operator; it obtains the required data via an open interface of the smart meter (offered on a non-discriminatory basis by the network operator to all interested parties). Consequently, obtaining consent is the most important obstacle for the use of smart meter data. If the required consent may be obtained, smart meter data may be used to provide smart home and security services as well as enhanced commercial offers (e.g., personalized advertisements).

\section{Concluding Remarks}

Current electricity market regulation makes use of a plethora of instruments that deal—each on its own — with different aspects of the energy and electricity market design. There is a law on electricity market regulation, on the promotion of renewable energy, on the use of hydropower, on the mitigation of greenhouse gas emissions; soon, there will also be a law on the gas market. The transformation path envisioned by the federal government, however, makes it necessary that these instruments operate as one system, enabling easy conversions from one form of energy into another. Although there are no legal impediments to conduct these conversions, there are no legal norms to facilitate conversions, either.

Current electricity market design focuses on breaking up vertically integrated monopoly structures by strict unbundling rules. As a matter of principle, these rules may take different forms: the incumbents either may be broken up along the value chain, or they may be forced to provide access to their networks. Successfully implemented in telecommunication markets, unbundling regulation helps competitors to enter the markets which are upstream and downstream to a network (i.e., the electricity grid). Unbundling, however, raises transaction costs (cost of regulation and enforcement, cost of lost synergies, etc.). In contrast to telecommunication 
markets, the electricity grid and electricity generation are not only complements but also substitutes: A lack of electricity in a certain area may be countered by ramping up generation or by adding grid capacity. Consequently, unbundling electricity markets requires procedures to coordinate the buildup of grid and generation capacity; these procedures need to replace the internal coordination within the integrated energy supplier. Since such outside coordination is costly, there is a vast literature that indicates that unbundling may not be so efficient, after all. ${ }^{43}$ Thus, efficient coordination of the participants in the electricity market may be difficult to achieve in a centralized energy system. In a decentralized energy system with many participants in ever-changing roles, efficient coordination may be impossible to obtain, in particular when using traditional command-and-control regulation. New instruments and procedures for adjudication and dispute settlement are needed but not within reach.

Many regulatory principles that govern energy and electricity markets have been developed for other infrastructure sectors-sectors that are also prone to network effects. The "postage stamp principle" that governs grid charges, e.g., has an obvious predecessor in postal markets; unbundling network access services from other services has been implemented in the telecommunication markets. These principles had their use when the monopolies in these network industries had to be broken up and when room had to be made for some competition. Today, other social goals have taken preeminence, such as security of supply and the mitigation effort regarding greenhouse gases. As the case study "aliunid" shows clearly, some of the old instruments hinder the transformation of the energy industry.

In the past, the energy industry was often not able to position itself at the forefront of innovation. This has changed, as the industry enters unchartered waters. To find effective and efficient solutions for the energy transformation, difficult first-order problems have to be solved: Centralized command-and-control regulation, on the national or on the European level, may not be suited to seek, find, and implement the most efficient solutions. To optimize a local "energy environment", locally adapted regimes might be needed. ${ }^{44}$ Research pioneered by Elinor Ostrom shows that local actors that are responsible for a localized resource may also solve second-order problems: They are able to develop and implement local rules and regimes that effectively and efficiently manage their resources, e.g., their local energy system. ${ }^{45}$ Today, such voluntary regimes, e.g., concluded by contracts or devised in communal regulation, are easily frustrated by the current top-down approach to the regulation of the energy system. ${ }^{46}$ Of course, fair access to these localized systems and appropriate protection of captive consumers will remain important and will remain a task for

\footnotetext{
${ }^{43}$ Hettich (2020), n. 38; Föhse (2014), n. 504.

${ }^{44}$ Ostrom (2005), p. 255 et seq.; see also Ostrom, Stein Rokkan Lecture, "Protecting Institutional Diversity", St. Gallen, 16 April 2011.

${ }^{45}$ See, e.g., Ostrom (1998), p. 2; Schlager (2002), p. 804.

${ }^{46}$ Ostrom (1990), p. 21 et seq.; see also Ostrom, Stein Rokkan Lecture, "Protecting Institutional Diversity", St. Gallen, 16 April 2011.
} 
central governance regimes. However, such goals also may be enforced by performance benchmarks and by processes to replace failing local regimes. ${ }^{47}$

Not every problem of the energy sector requires a European solution. But what is sure: The regulatory innovation needed to manage a rapidly transforming energy system may not be found by sticking to traditional bureaucratic processes and procedures. ${ }^{48}$ We need approaches that are systemic, that provide leeway for learning as well as trial and error processes, and that are quickly able to identify and scale successful experiments as well as to shut down the ineffective ones.

\section{References}

Electricity Commission (2019) Fragen und Antworten zu neuartigen und dynamischen Netznutzungs- und Energieliefertarifen: Februar 2019 (Update September 2019). Available at https://www.elcom.admin.ch

European Commission (2016) Commission Staff Working Document accompanying the proposal for the Directive on common rules for the internal market in electricity, the Regulation on the electricity market, the Regulation establishing a European Union Agency for the Cooperation of Energy Regulators, the Regulation on risk preparedness in the electricity sector, $\operatorname{SWD}(2016)$ 410 final, Brussels 30 November 2016

Federal Council (1988) Botschaft vom 21. Dezember 1988 betreffend den Bundesbeschluss über eine sparsame und rationelle Energieverwendung (Energienutzungsbeschluss, ENB). Federal Gazette BB1 1989 I 497

Federal Council (2005) Botschaft vom 3. Dezember 2004 zur Änderung des Elektrizitätsgesetzes und zum Stromversorgungsgesetz. Federal Gazette BB1 20051611

Federal Council (2018) Revision des Stromversorgungsgesetzes (volle Strommarktöffnung, Speicherreserve und Modernisierung der Netzregulierung). Erläuternder Bericht zur Vernehmlassungsvorlage (Oktober 2018). Available at https://www.admin.ch

Federal Council (2021) Botschaft zum Bundesgesetz über eine sichere Stromversorgung mit erneuerbaren Energien. Federal Gazette BB1 20211666

Föhse KS (2014) Die rechtliche Ausgestaltung der nationalen Netzgesellschaft im Stromversorgungsgesetz (StromVG). Dike, St. Gallen

Hettich P (2014) Kooperative Risikovorsorge: Regulierte Selbstregulierung im Recht der operationellen und technischen Risiken. Schulthess, Zurich

Hettich P (2020) Infrastrukturverfassung. In: Diggelmann O, Hertig Randall M, Schindler B (eds) Verfassungsrecht der Schweiz. Schulthess, Zurich 2020, Vol. III, VIII.9

Hettich P, Rechsteiner S (2014) Datensicherheit und Datenschutz im Smart Grid. Jusletter 27 October 2014. Available at https://jusletter.weblaw.ch

Hettich P, Walther S (2015) "Hype" um Batterien lässt das Verteilnetz vergessen: Skizzen zu einer sachgerechteren Anlastung der Netzkosten. Bulletin SEV/VSE 106(12):24-26

Hettich P, Walther S, Schreiber Tschudin S (2015) Schweiz ohne Stromabkommen. Dike, St. Gallen

Hettich P, Walther S, Wohlgemuth D, Camenisch L, Drittenbass J (2017) Strommarkt 2023: Quotenmodelle im Zieldreieck von Umweltverträglichkeit, Wirtschaftlichkeit und Versorgungssicherheit. Dike, St. Gallen

\footnotetext{
${ }^{47}$ Karkkainen (2002), p. 193 et seq.; Karkkainen (2006), p. 893; Sabel and Simon (2004), p. $1020,1062$.

${ }^{48}$ See for cooperative approaches to regulation Hettich (2014), p. 269 et seq.
} 
Hettich P, Thaler P, Camenisch L, Hofmann B, Petrovich B, Wüstenhagen R (2020) Europeanization of the Swiss Energy System. Dike, St. Gallen

Karkkainen BC (2002) Collaborative ecosystem governance: scale, complexity, and dynamism. Virginia Environ Law J 21:189-243

Karkkainen BC (2006) Information-forcing environmental regulation. Florida State Univ Law Rev 33:861-902

Knill C, Lehmkuhl D (2002) The national impact of European Union regulatory policy: three Europeanization mechanisms. Eur J Polit Res 41(2):255-280

Ostrom E (1990) Governing the commons: the evolution of institutions for collective action. Cambridge University Press, New York

Ostrom E (1998) A behavioral approach to the rational choice theory of collective action. Am Polit Sci Rev 92:1-22

Ostrom E (2005) Understanding institutional diversity. Princeton University Press, Princeton

Rechsteiner S, Steiner T (2018) Datenschutz bei intelligenten Mess- und Steuersystemen. Jusletter 11 June 2018. Available at https://jusletter.weblaw.ch

Sabel CF, Simon WH (2004) Destabilization rights: how public law litigation succeeds. Harv Law Rev 117:1015-1101

Schlager E (2002) Rationality, cooperation, and common pool resources. Am Behav Sci 45:801-819

Swiss Federal Office of Energy (2021) Schweizerische Statistik der erneuerbaren Energien: Ausgabe 2020. Available at https://www.bfe.admin.ch

Van Baal P, Finger M, Fischer M, Maggetti M, Morger L, Pflieger G, Refle J-E (2019) The Swiss energy transition and the relationship with Europe: Complementary study NRP70 Energy Turnaround (unpublished report)

Walther S (2014) Kooperative Steuerungsinstrumente im schweizerischen Stromversorgungsrecht. Dike, St. Gallen

Peter Hettich is Director with the Institute of Public Finance, Fiscal Law and Law and Economics (IFF-HSG) and Professor for public law at the University of St. Gallen, St. Gallen, Switzerland.

Open Access This chapter is licensed under the terms of the Creative Commons Attribution 4.0 International License (http://creativecommons.org/licenses/by/4.0/), which permits use, sharing, adaptation, distribution and reproduction in any medium or format, as long as you give appropriate credit to the original author(s) and the source, provide a link to the Creative Commons license and indicate if changes were made.

The images or other third party material in this chapter are included in the chapter's Creative Commons license, unless indicated otherwise in a credit line to the material. If material is not included in the chapter's Creative Commons license and your intended use is not permitted by statutory regulation or exceeds the permitted use, you will need to obtain permission directly from the copyright holder.

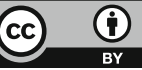

